\title{
1. Business ethics: facing the challenge in an uncertain world
}

\author{
Abbas J. Ali
}

Arguably, the most important subject in the field of business that should top the priorities of Muslim scholars is business ethics. As current social, economic and political events reveal, misunderstandings about Islamic ethics are common among both ordinary and educated Muslims. Ismail and Zali (2014), for example, in their study of Islamic banking, indicated that most institutions have little understanding of ethics. This phenomenon is not only limited to large corporations, but includes small and medium-sized firms. These misunderstandings are deeply rooted in societies with Muslim majorities (CMM). For this very reason, ethics should not be treated as an isolated subject, but as a social and political concern that acquires historical significance in today's world. However, under prevailing conditions (as in toleration of ethical violations and commonality of fraud and corruption), it will be difficult if not impossible to eradicate widespread fraudulent and corrupt practices and validate the practicality and relevance of religious instruction.

The misunderstandings and lack of commitment to Islamic ethics in countries with Muslim majorities should not be viewed as minor issues. Ethics is the foundation for a healthy and vibrant society. In the absence of ethics, waste of economic resources and talent becomes a predicated outcome. Countries that have achieved economic progress and viable human capital have been characterized by moral clarity, a disciplined ethical stance, articulation of an ethical system and transparent operations. In CMM societies, subordination of ethics to the will of those in power and lack of familiarity with Islamic ethics and the reasons behind them, over centuries, have produced two negative qualities: indifference and greed. The first, indifference, creates an environment where irresponsible citizens flourish and toleration of corruption becomes part of the social fabric. The second, greed, is a product of the interplay of several factors. Chief among these factors are an unfamiliarity with religious prescriptions on economic and social issues, political corruption and suppression, lack of legal and disciplinary actions, limited access to economic opportunities and a propensity to and the quest for materialism, 
especially as CMM societies have been merged into the global marketplace without building sound legal, economic and educational institutions.

Being indifferent or greedy violates two of the major foundations of Islamic business ethics. These are: (1) ehsan; and (2) the acquisition of benefits and repulsion of harm. The first, ehsan, conveys kindness in dealing with others and a tendency to provide assistance to those in need. More importantly, it implies the willingness of a person to display flexibility in tracking his/her rights, while giving others more than their rights. This was highlighted by Ibn Arabi (1997, p. 310; died 1240) when he reflected on ehsan stating:

Maintain a fair balance between you and God and between yourself and others. If you are given something, it is fine if it is less than what you had expected and it is perfectly fine if you take less than what you are entitled to. However, if you cannot observe this, then be just in your dealings and give each what he deserves.

Likewise, Al-Maki (1995, p. 561; died 996) differentiated between justice and ehsan stating, 'Justice is taking what is right for you and giving what is right to others. Ehsan is absolving part of your right and giving more than what you owe to others; to be among those who do the right things.' This, of course, is contrary to corruption and greed, which by necessity implies taking that which does not belong to a person, a reduction of others' rights and/or inflicting damage either to private or public property.

The principle of 'acquisition of benefits and repulsion of harm' is probably the most misunderstood and the most dishonored in CMM. This should not come as a surprise. In fact, its violation is not only common, but among ordinary citizens and the elite alike it has been thought of as perfectly fine in business dealings. While cultural discontinuity plays a major part in violating the principle, the quest for materialism, which has produced flexible ethics, shares the blame. It should be noted, however, that there is a traditional segment among the Muslim population that has kept the practice of the principle alive and appreciated. The practice of 'acquisition of benefits and repulsion of harm' by this segment demonstrates that ethical standards are observed and human dignity is respected. In the business world, it sends a powerful message that any dealings and transactions must coincide with the interests of the society and should not result in injury to any party in the marketplace or to communities at large.

In these modern times and in an era of rapid business changes, there is an urgent need to rethink not only business priorities, but the validity of 
the principles that were set centuries ago. The pressing question is: are the aforementioned principles still useful and valid? The answer, in this volume, is yes. Both the principles of ehsan and 'acquisition of benefits and repulsion of harm' are not only relevant to today's business, but are essential for ensuring a community where business transactions are morally driven and where fairness, if not generosity, governs interactions. Moreover, both principles, if observed, contribute to safeguarding human dignity and freedom of individuals. These are issues that are often neglected by both the general media and in scholarly outlets in CMM. This is especially true, as scholars at this infancy stage of research on business ethics have been unable to go beyond religious recitation. But the interweaving of these principles with business and market issues should not be taken lightly. These two principles strengthen not only prospects for prosperity, but, more importantly, set the stage for harmonious and cooperative relationships among people in the marketplace and beyond. These sought relations are assumed to be inclusive and span complex networks that optimize relations between individuals and corporations, between customers, suppliers, labor, government and corporations, and among corporations themselves.

How these principles ease transactions that are morally driven is a matter that should be given priority in research agendas. However, easing market transactions is impossible to understand without viewing the dialectic relationship between business actions and serving the people. That is, what should be underscored is that business transactions have a purpose that goes beyond profit making to include attending to changing societal needs and priorities, while continuously improving economic and social offerings. This is best described as socially driven business. This perspective highlights the commitment of business to society, not because it is good practice to increase profits and gain the loyalty of customers, but because social involvement and participation is a normal aspect of business activities and business is characteristically linked to its social milieu. This relationship is not merely a research exercise, but, more importantly, it is an integral part of the principles of the faith and is anchored in the concepts of ehsan and 'acquisition of benefits and repulsion of harm.'

For ehsan, the implied attitude is that one is not only kind to other players, but also generous. In both cases, market players are motivated and energetically participate in transactions. The latter are viewed as desirable acts that enhance trust in market institutions and make it possible for others to generate benefits to all. The Qur'an (4:29) instructs that any transaction must be an outcome of mutual agreement, free of any deception or coercion: 'Let there be amongst you trade by mutual 
good-will.' The Prophet encouraged mercy in transactions and in business dealings, stating, 'May God have mercy on the man who is generous when he buys and when he sells and when he demands' and that God rewards those who 'give respite to one in easy circumstances and forgives one who is in straitened circumstances' (quoted in Muhammad Ali, 1977, pp. 294-5). What these instructions and the discussions reveal is that kindness and generosity are embedded in Islamic thinking and philosophical outlook. That is, Islamic thinking not only encourages business people, irrespective of their craft, to optimize cooperation and ease interaction without deception, but also makes it mandatory for them to act mercifully in the marketplace and to help each other.

The principle of 'acquisition of benefits and repulsion of harm' vividly captures the fact that business activities, like life in general, are focused on serving mankind. It is for this particular reason that the measure of the permissibility and validity of any business is the degree to which it serves people and does not generate any harm to either individuals or society at large. The Qur' an (2:148) instructs, 'To each is a goal to which God turns him; then strive together (as in a race) towards all that is good' and states (49:13), 'The noblest of you in the sight of God is the best of you in conduct.' The Prophet articulated this message clearly when he pronounced, 'The best people are those who benefit others' and 'God loves those who benefit others.' A commitment to these instructions deepens trust in market institutions, minimizes risk and motivates people to take initiative and engage in various activities without fear of losing their wealth due to manipulation, deception or fraud.

In terms of human dignity and freedom of the individual, the principles of ehsan and the 'acquisition of benefits and repulsion of harm' offer deep insights into the significant role of mankind and the necessity to provide adequate measures to ensure the freedom and dignity of individuals. The Qur'an places a person in the highest regard and a human being is treated as the custodian of the environment. The freedom of individuals conveys that, in a changing world, a human being remains the primary actor in shouldering responsibility and observing religious prescriptions. Indeed, the Qur'an positions human beings in the most prestigious place stating (2:30), 'Behold, thy Lord said to the angels: "I will create a vicegerent on earth." Furthermore, man is God's trustee in the universe. The Qur' an (33:72) manifestly states: 'We offered the trust to the heavens, the earth, and the mountains, but they refused to undertake it, being afraid thereof. But humans undertook it.' These two positions, the vicegerent and the trustee, have built the foundation for a person to be free, but responsible - that is, free to undertake what is appropriate and to be responsible for his/her action in life and the 
hereafter. This is well reflected in the Qur'an (17:15): 'Whoever receives guidance receives it for his own benefit: who goes astray does so to his own loss'; and (17:84), 'Everyone does as he wants. Your Lord knows who has the right guidance.' For these particular, and other reasons, Islamic prescription, as clarified in the Qur'an and the Prophet's sayings, does not sanction the use of the term 'royalty.' The word implies coercive use of power, absolute authority and divine right, which are contrary to the dignity of the individual and that everything on earth is made to serve mankind. Furthermore, royalty as a concept and as a practice violates the principles of ehsan and 'repulsion of harm and acquisition of benefits.'

In addition, the Qur' an underscores that each person is responsible for his/her actions stating (6:164), 'And every soul earns not [blame] except against itself; no bearer of burdens will bear the burden of another.' In addition, freedom of individuals is impossible to realize without giving each the opportunity to pursue their legitimate needs and careers. The Qur'an states (92:4), 'Verily, (the ends) ye strive for are divers'; and (53:39) 'A human can have only what he strives for.' It is these instructions that set the stage for both principles (ehsan and 'acquisition of benefits and repulsion of harm') to govern human relations and transactions. And since everything on earth is created to serve mankind, harming any individual or obstructing his/her pursuit represents an abhorrence to religious instructions. Indeed, the faith of any individual will not be perfected if a person does not love for others what he/she loves for themselves. The Prophet stated, 'What you love for yourself you should love for others' (quoted in Al-Ghazali, 2006, p. 395) and 'God has no mercy on a person who is not merciful to others' (quoted in Muhammad Ali, 1977, p. 386). Both sayings reaffirm too that serving others is part of a person's responsibility and that doing what is good benefits all members in the community. This again validates the fact that, in Islamic teaching, while personal freedom is valued, its importance stems primarily from advancing benefits to society and in deepening the knowledge of responsibility toward the community. Personal and community affairs are neatly interwoven in the quest for generating benefits and creating value to others. The interplay between individual freedom and societal interests creates a type of mechanism that safeguards just and smooth transactions, while reassuring market actors, especially those in need, that the rights of each are defended.

What should be made clear is that in a world where business globalization deepens interdependence and connectivity across nations, the challenge to principled conduct and ethical obligations is mounting. The challenge, as we discussed earlier, existed a long time ago, but at the 
present time its magnitude has multiplied and it is much more comprehensive than in any period in history. This often translates into replacement of traditional beliefs and value with alluring factors, such as materialism and conformity to new globalization rules. While this trend may be appealing to various segments, its impact on individuals and the community is far reaching. This is what makes the role of scholars important in sensitizing people to that which is genuine and beneficial and avoiding that which is harmful. The problem, however, is that some scholars are closer to ruling powers than to ordinary citizens; they are unfamiliar with ethical and historical precedents; they engage in consulting and thus prefer not to divert attention or resources to subjects that might be controversial.

The last point is exemplified by several chapters in this volume that focus on Islamic finance and banking. Issues that we seek to address in this volume, such as the Islamic ethical system, state and market functions, pricing and exchange, competition and consumer wellbeing, cultural differences and interpretation of Islamic business ethics, and so on, are avoided by some scholars. However, these issues are timely and needed in order to articulate Islamic enlightened thought and enable scholars and policymakers alike to refine Islamic thought away from an unprincipled ideology that prohibits discovery, imagination and building economically and scientifically vital societies. These prohibitions are often issued by non-academic official religious figures who place limitations on the power of mind. However, the aforementioned issues require special academic and religious expertise, in addition to some antecedentbased reasoning. This is not encouraged by the existing ruling elite who view intellectual and academic research as either apolitical or unnecessary endeavor. Nevertheless, the field of Islamic business ethics is promising intellectually and is professionally rewarding. In fact, responsible scholars in the near future may find this field of study indispensable in their quest to build sound theoretical perspectives and eradicate corruption. This volume, therefore, is a modest contribution to research on Islamic business ethics, which brings together scholars from various fields and countries.

In Chapter 2, I address the ethics of knowledge and scholars' responsibility. In particular, I look at issues related to virtue of knowledge, knowledge in life, trade knowledge, ethical frameworks, scholars' moral responsibilities and ethics of scholars. The latter is distinct and tends to situate learned individuals in a position of neutrality and prudence, prestige and humbleness, faithfulness and thankfulness, persistency and dedication. Specifically, the ethics of the scholar should encompass at least six principles. These are: not profiting from his/her knowledge, 
independent thinking, refraining from putting down others, tolerance, declaring their unfamiliarity in matters of which they have no knowledge and practicing what is preached.

Imad-ad-Dean Ahmad, in Chapter 3 (Individual rights and responsibilities, morality, relativism and self-interest), addresses five issues: absence of relativism in Islam, right actions in an individual's self-interest, Islam's methodological individualism, rights and responsibilities and application to management. He asserts that Muslims have no history of guidelines for good governance that will allow businesses to grow beyond the size of a successful family business. These guidelines, he argues, would be practical and useful for insight on what should be done. In his discussion, he underscores three important points that are neglected in the business literature on Islam. These are: (1) the Muslim belief in the need for a moral filter that replaces the sovereignty of the consumer is not an obstacle to entrepreneurship; (2) unwavering commitment to the importance of property rights; and (3) existence of absolute morality.

In Chapter 4 (Religion, virtuous conduct, justice, vocation and the ethics of hard work: a descriptive view of Islamic sociocultural systems and economics) Hasan Shahpari and Tahereh Alavi Hojjat explore the issues of equity and justice in relation to the structure of work, the economy, social class and mobility and in the context of the Islamic sociocultural system. To differentiate Islamic thinking on these matters, the authors discuss the sociological background, work and justice, ethics of balance, economic development and ethics of hard work. In addition, the authors suggest that Islamic taxation seeks to establish an ideal community characterized by cohesiveness and fairness; virtues fostered by a non-political Islamic vision.

In Chapter 5 (The nature of business social ethics in mainstream and Islamic worldview) Masudul Alam Choudhury discusses Islamic ethics and differentiates Islamic business social ethics from those commonly found in the West. In particular, he points out the distinct nature of social ethics and its importance as an endogenous behavioral force that can affect business and economic venues. He highlights the roots of social ethicality that influence business and economics in comparative religions and cultures besides simply knowing the qualitative perspectives. To make his point clear and to validate his arguments, he relies on empirical evidence. The author then constructs an endogenously interrelated social and ethical embedding of business and economics issues. Professor Choudhury is critical of the lack of theoretical perspectives and models that capture the intent of Islamic law. He suggests that the essential Islamic worldview of business social ethics, as pronounced by the 
maqasid as-shari'ah, is nowhere in sight. He concludes that no challenging contribution has been made by intellection in Islamic ethics, either in conceptualization or practice of business social ethics otherwise found in mainstream intellection on this topic.

Said Elfakhani and Yusuf M. Sidani, in Chapter 6 (Uncertainty or 'gharar' in contracts under the Islamic ethical code), discuss the issue of uncertainty, 'gharar,' within an Islamic framework. They reflect on different types/forms of gharar and highlight some ethical considerations of gharar. Moreover, they briefly explain some Islamic alternatives to gharar. They assert that contractual items under gharar involve unknown issues or uncertainties that are harmful to society and, hence, are in conflict with Islamic prescriptions. They conclude that there is a moral challenge facing Islamic jurisprudents. This challenge is to maintain the objectives of shariah - that is, of fairness, truthfulness, transparency and justice - while neither blocking the growth of business community development nor suffocating Muslims' legitimate needs for acceptable financing.

Jonathan A. J. Wilson, in Chapter 7 (Brand Islam and the marketing of Muslim ethics to a global audience), discusses the cultural impact and implications of Islam on the ethical elements of personal professionalism and practice. The chapter showcases three areas: establishing an Islamic paradigm that harmonizes classical schools of thought with contemporary business and management social sciences; Islamic marketing and halal branding; Muslim consumer behavior; and a sociocultural Islamic economic ontology. Wilson argues that the emergent phenomenon of Islamic marketing provides a fertile ground for new concepts critical to generative theory building. In his definition of Islamic marketing, Wilson suggests that Islamic marketing exists on three interdependent levels: the acknowledgment of a God-conscious approach to marketing from a marketer's and/or consumer's perspective, which draws from the drivers or traits associated with Islam; a progressive school of thought, which has a moral compass that tends toward the ethical norms and values of Islam and how Muslims interpret these from their varying cultural lenses; and a multilayered, dynamic and contextual gestalt phenomenon of Muslim and non-Muslim stakeholder engagement, which considers the creation and preservation of explicit, implicit and tacit signaling.

Luqman Zakariyah, in Chapter 8 (Ethical considerations in 'Islamic' marketing and promotion: a spotlight on the Islamic Bank of Britain), traces the historical progression and evolution of Islamic banking. He explains, in detail, Islamic approaches to marketing financial products. He places an emphasis on whether or not Islamic products in the UK are promoted and marketed according to Islamic perspectives. Zakariyah 
relies on certain cases and examples to validate his arguments. $\mathrm{He}$ contends that while Islamic ethics are transcendent in nature and incorporated into all Islamic concepts, the secular mode of ethical decision making puts more emphasis on 'positivistic approaches' at the expense of transcendence. He concludes that in the West, especially in Britain, correct application of totally Islamic ethics is unrealistic.

In Chapter 9 (Leadership in Islam: ethical and theoretical foundations), I attempt to map the theoretical perspectives of Islamic thinkers on leadership. In the course of presenting historical and theoretical perspectives on the subject, I discuss the ethical underpinnings of each perspective and development. The chapter tackles pressing issues that are relevant to today's world and business developments: the nature of leadership in Islam; its foundations and social/political dimensions; the practical reasoning for Islamic leadership thought; the practice of leadership; and the gap between practice and idealism. Furthermore, the chapter examines attribution theory and provides evidence from Islamic history and teachings that reaffirm the validity of the attribution approach. In addition, the chapter makes the case that internalization of Islamic teachings and observation of its pillars of leadership will likely lead to ethical and responsible conduct. I argue that this internalization will strengthen the moral imperative of doing good deeds and meeting societal interests.

In Chapter 10 (Power and authority: the Ten Commandments perspective), I present the Islamic Ten Commandments and compare them to the often discussed Jewish and Christian Ten Commandments. The Islamic Ten Commandments are seldom considered by Muslim scholars. In fact, the subject is, for the most part, largely overlooked. The possibility is that Muslim ethics are broader and have been articulated in various forms and frameworks. This, however, does not necessitate the negligence of a subject that is relevant to both general life and business practices. In this chapter, I not only present the implication of the Ten Commandments on power and authority, but underscore scholars' responsibilities in confronting society's ills. The chapter stresses that to tackle such a subject, scholars must have a sense of history and commitment to their intellectual duties as catalysts for change. That is, scholars should not be either passive actors or spectators as this would be to represent indifference and sycophancy.

In Chapter 11 (Islamic finance and social justice: a reappraisal) Raza Mir and Muqtedar Khan attempt to contrast the principles of Islamic humanism against the practices of Islamic finance. The objective is to uncover potential tensions and offer ways in which these tensions may be resolved. They survey the existing instruments of Islamic finance as they 
are being practiced in various parts of the world. In addition, they articulate the principles of economic justice as expressed in the Holy Qur'an and the sayings of the Prophet. The authors argue that the practice of Islamic finance does not live up to the promise and prescriptions of the faith. Thus, the authors offer ways in which it can be oriented toward social justice issues.

Hussain G. Rammal, in Chapter 12 (Managing the ethical aspects of Islamic banking and finance), explores why our knowledge about the management and governance structures of the system is limited. The chapter describes the governance and management structures in Islamic financial institutions. Furthermore, he explains the role of Shariah Supervisory Boards and related standard-setting institutions and regulatory bodies in influencing the operations of the financial institutions. The author brings to the surface certain inconsistencies in standards and regulations across national boundaries that continue to limit the efforts being made to standardize governance practices in the sector. The author has noticed, for example, that while some countries require banks to have a shariah board or advisor, others do not.

In Chapter 13 (The ethics of Islamic accounting) Yusuf M. Sidani discusses aspects of financial accounting. While he offers a religious insight into accounting ethics, with special emphasis on the Islamic perspective, he argues that over centuries scholars and researchers have ignored how accounting has developed in the Islamic world. Consequently, the potential for an Islamic perspective on developing an Islamic accounting system and theory has not been articulated. However, Sidani notes that, because of the phenomenal growth in Islamic banking and finance in recent decades, there has been some development in Islamic accounting. Sidani presents certain elements that differentiate Islamic accounting from the conventional well-established accounting systems.

The last two chapters focus on work ethics. In Chapter 14 (Work ethics in GCC countries: current challenges and the road ahead), Yusuf M. Sidani reflects on the evolution and the reality of work ethics in the Arab Gulf Council (GCC). He first highlights the most visible social and economic elements that place the GCC countries apart from other Arab states. These are: work segregation; dependency on foreign labor; reliance on oil; increasing citizens' share in the workforce; divergent human resource (HR) practices; entitlements; stereotyping of citizens; and female development and growth. Sidani concludes that there are difficulties in bringing work ethics in GCC countries in line with Islamic work ethics. He suggests some avenues to alleviate this lingering problem. 
In Chapter 15 (Islamic work ethics and organizational commitment: a case of Jordanian Islamic banks) Saad G. Yaseen, Dima Dajani and Sama Mazen Al-Taee have conducted an empirical study in Jordan utilizing certain elements of Islamic work ethic (IWE) and organizational commitment. The authors have found that IWE constructs, namely perceived worship, effort, cooperation and moral responsibility, have a positive impact on organizational commitment. They suggest a framework to enhance work ethics and improve organizational commitment.

\section{CONCLUSION}

As indicated earlier, ethics is the foundation for a just and prosperous society. Al-Mawardi (2002, p. 174) equated ethical conduct with joy. $\mathrm{He}$ quoted a priest who pronounced, 'Each day I do not disobey God, is a celebration.' Without ethical conduct it is impossible for prosperity or the wellbeing of individuals to materialize. The temptation to gain wealth and be ahead of others may seem attractive in the short term. However, in the long term, individuals and enterprises may suffer deeply. Generally speaking, an absence of ethical standards leads to chaos, mistrust and dysfunctional rivalry. In the business world, the business of ethics results in mistrust, lack of openness and cooperation, weak market institutions, disregard of private property, flourishing of fraud and obstruction of entrepreneurship.

For these very reasons, ethics assumes social and economic significance. It is good ethics that enhances societal wellbeing and growth. That is, good ethics is a prerequisite for achieving sustainable economic and social goals. The Prophet asserts that good ethics and generosity lead to 'complete faith.' Abu Othman Omer ibn Bahr Al Jahiz (1998), who died in 868, underscored the importance of ethics in eliminating greed and minimizing societal problems. In his correspondences, he quoted Shabib Ben Sheeba who said, 'Good ethics is better than multiplied wealth' (see Ben Hassan, 2000, p. 268).

In this volume, certain ethical and contemporary challenges are identified. Implications for researchers are provided and minefields in today's world are briefly addressed. Though this volume is a small contribution to the study of ethics, we hope that some important subjects that are not covered in this volume will be addressed in the future. Indeed, the study of ethics from an Islamic perspective, especially in terms of business, is a journey with endless possibilities. 


\section{Handbook of research on Islamic business ethics}

\section{REFERENCES}

Al-Ghazali, A. H. (2006), Collection of Letters, Beirut, Lebanon: Dar Al-Fikr.

Al Jahiz, Abu Othman Omer ibn Bahr (1998), Book of Misers, Beirut, Lebanon: Dar Sader. Al-Maki, A. T. (1995), Guot al-Gwlob (Nourishment of Hearts), part 2, Beirut, Lebanon: Dar Sader.

Al-Mawardi, Abu al-Hassan (2002), Kitab Aadab al-Dunya w'al-Din (The Ethics of Religion and of this World), Damascus, Syria: Dar Ibn Khather.

Ben Hassan, Imam Abdulallah (2000), Correspondences of Al Jahiz, vol. 1, Beirut, Lebanon: Dar al Kiteb al Alelmeha.

Ibn Arabi, Mohammed Shehab Al Dean (1997), Correspondences of Ibn Arabi, Beirut, Lebanon: Dar Sader.

Ismail, Abdul Ghafar and Nor Asmidah Zali (2014), 'Ethics in Relation to Islamic Finance Activities,' Islamic Research and Training Institute, Islamic Development Bank Group, working paper, $1435-07$.

Muhammad Ali, M. (1977), A Manual of Hadith, Ithaca, New York: Olive Branch Press. Qur'an: English Translation of the Meanings and Commentary (1989), Al-Madinah Al-Munawarah, Saudi Arabia: King Fahd Holy Qur-an Printing Complex. 